"Insight into supply chain management in a municipal context"

\begin{tabular}{|c|c|c|}
\hline AUTHORS & Intaher Marcus Ambe & \\
\hline ARTICLE INFO & $\begin{array}{l}\text { Intaher Marcus Ambe (2016). Ins } \\
\text { municipal context. Public and M } \\
\text { doi:10.21511/pmf.5(2).2016.02 }\end{array}$ & $\begin{array}{l}\text { ain management in a } \\
\text { (2), 20-29. }\end{array}$ \\
\hline DOI & http://dx.doi.org/10.21511/pmf.5( & \\
\hline RELEASED ON & Tuesday, 06 December 2016 & \\
\hline JOURNAL & "Public and Municipal Finance" & \\
\hline FOUNDER & LLC "Consulting Publishing Con & erspectives" \\
\hline & & $\begin{array}{l}\text { ニ- } \\
\text { =E: }\end{array}$ \\
\hline NUMBER OF REFERENCES & NUMBER OF FIGURES & NUMBER OF TABLES \\
\hline
\end{tabular}

(C) The author(s) 2023. This publication is an open access article. 
Intaher Marcus Ambe (South Africa)

\title{
Insight into supply chain management in a municipal context
}

\begin{abstract}
Supply chain management is strategic to the quest for service delivery excellence in South African municipalities. The supply chain journey in South African municipalities started in 2005 with reforms to introduce internationally accepted procurement best practices. The previous system failed the country due to deficiencies and malpractices resulting from the interpretation, implementation and governance of the preference procurement policy. Today (2016), supply chain management has become a talking point on which citizens are raising major concerns and it is perceived as being handled in a way that financially benefits few individuals. Laws and regulations governing municipal supply chain management are intentionally ignored or flouted by municipal officials resulting in corruption, fruitless, wasteful and unauthorized expenditure. In an effort to address these challenges, the National Treasury continuously provides guidance in terms of policy revision, clarity in the provisions of the supply chain management policy, as well as training to supply chain management officials. This article provides an insight into supply chain management practices in a municipal context in South Africa. It highlights the status, challenges and way forward for the implementation of supply chain management in a municipal environment.
\end{abstract}

Keywords: insight, supply chain management, municipality, public procurement, South Africa. JEL Classification: M38.

\section{Introduction}

Supply chain management (SCM) has become an exceptional strategic concept not only to the private sector, but also to governments (Nomvete, 2009). In recent years, the regulation of government spending has gained significance due to SCM, especially with regard to the procurement of goods and services by means of fair, competitive and cost-effective systems and processes (Bent, 2014, p. 14). As indicated by Bent (2014, p. 14), in line with regulated systems and processes, government has realized the importance of SCM as a socioeconomic development tool. For example, SCM is one of the key tools and mechanisms enabling the South African government to implement policy for socioeconomic development and transformation. Traditionally, SCM has been misunderstood and undervalued. Its strategic importance has not been recognized, and it has been undercapacitated (National Treasury [NT], 2015, p. 1).

SCM was adopted in South Africa, based on the findings of the review of the Joint Country Assessment Review with the World Bank initiated by the National Treasury in 2001. In 2005, a SCM policy document titled "Supply chain management: a guide for accounting officers and authority in municipalities and municipal entities" was developed to guide the implementation of SCM. The main objective for the adoption was to use SCM as a tool to manage "procurement", since there was lack of interpretation, accountability and implementation of the preferential procurement policy adopted after the first democratic elections. The

\footnotetext{
(c) Intaher Marcus Ambe, 2016.
}

Intaher Marcus Ambe, Professor, Department of Entrepreneurship, Supply Chain, Transport, Logistics \& Tourism, University of South Africa (Unisa), South Africa. system functioned under the banner of the "tender" board (centralized system of procurement). With the adoption of SCM, a roll-out implementation plan was established and a generic SCM policy developed. Each government institution had to customize the generic SCM policy to suit its needs and the establishment of SCM units to give effect to the requirements of the legislation (Bent, 2014, p. 15). With the timeframe, the National Treasury also embarked on training to educate and capacitate SCM practitioners and numerous education and training institutions came to the fore.

However, to date (2005-2016), SCM in municipalities over the years has been characterized by fraud and corruption despite the effort of the National Treasury. To a great extent, the intended outcomes for the adoption of SCM have not fully been achieved. National Treasury (2015) asserted that despite the adoption of SCM policies and practices in municipalities, its implementation remains a challenge. SCM practices in South African municipalities are deteriorating (Turley and Perera, 2014). While some municipalities are improving, the majority of the municipalities still derail due to supply chain failures. According to the Auditor General reports, only $5 \%$ and $9 \%$ of municipalities in the years 2011-2012 and 2013, respectively, had clean audit outcomes. In 2015, none of the municipalities in the North-West Province had a clean audit. SCM plays a greater role for poor audit outcomes such as irregular expenditure, lack of basic controls, as well as lack of supply chain skills. Boateng (2008) asserted that municipalities are under increasing pressure to tackle issues around SCM. This pressure does not only come from the service providers and the general public, but the media is also becoming more interested in stories about procurement and SCM (Business Day Report, 2011). 
There are daily reports of irregularities in newspapers, on television, radio and social media, which are signs that people feel that they are not receiving the quantity or quality of services they need. SCM has a critical role to play in service delivery in municipalities. Furthermore, the National Treasury SCM Review (2015) revealed that there are constant allegations of corruption and inefficiency in municipalities. SCM was only considered to be a strategic function in 2014, hence, the reason for imperfection and challenges according to the National Treasury (2015). SCM has, therefore, been offered a strategic position and the office of the Chief Procurement Officer was established to oversee and reinforce the implementation of SCM.

In light of the discussion above, this article intends to shed light on the insights of SCM practices in a municipal context in South Africa. The article based on a theoretical review provides a perspective of SCM in global context and, then, presents the state of SCM practices in municipalities from a South African point of view. It made use of a case analysis of the Auditor General's report of the state of SCM practices in municipalities of the North-West Province. Furthermore, the challenges of municipal SCM implementation from a national perspective and the way forward are discussed. This article is strategically important, as it makes a contribution to the body of knowledge regarding SCM in municipalities. It should be reiterated that most of the literature on SCM so far has been in the private sector. According to Korosec (2003), the majority of SCM literature that does exist focuses primarily on private sector transactions or on international governments owing to the fact that SCM has been used in both of these arenas for almost two decades. Notwithstanding, many professional government organizations have indicated that SCM could hold great promise in enhancing public procurement systems. This article serves as a reference for researchers both in South Africa and abroad, since there are limited studies on government SCM globally.

\section{Global perspective of supply chain manage- ment}

SCM is an important concept in today's business environment, as it contributes significantly to the bottom line (Agus, 2011, p. 269). According to Arlbjørn, Freytag \& de Haas (2010, p. 277), SCM has gained wide acceptance in recent years due to the increasing customer demands for quality, delivery and speed (Malhan, 2015, p. 21). The term SCM is inspired by the management of the product flow that should be delivered to citizens or businesses as it passes through several organizations. The main objective of SCM is to satisfy end users and increase profitability for the organization (Peng, Lawrence, Snyder, Lim and Liu, 2011, p. 1).
According to the Council of Supply Chain Management Professionals (CSCMP, 2007), "Supply chain management encompasses the planning and management of all activities involved in sourcing and procurement, conversion, and all logistics management activities. It also includes coordination and collaboration with channel partners, which can be suppliers, intermediaries, third-party service providers, and customers". In a functional sense, this focus on activities and relationships implies that logistics, marketing, purchasing/supply, and production/operations are involved in SCM.

The Institute for Supply Chain Management (2014) defines SCM as the identification, acquisition, access, positioning and management of resources and related capabilities that an organization requires or potentially desires in the achievement of strategic objectives.

Following the definitions, it can be asserted that SCM encompasses the planning and management of all the activities involved in sourcing and procurement, conversion, and all logistics management activities. Importantly, it also includes coordination and collaboration with channel partners, which can be suppliers, intermediaries, third-party service providers and customers. SCM can also be approached from different disciplines (Arlbjørn, Freytag and de Haas, 2011, p. 277), namely logistics, purchasing, transportation, operations management, marketing and research (De Haas, 2011). The concept of SCM can also be applicable to different industries, sectors and countries. However, it should be reiterated that most research on SCM is from the private sector perspective. Little research has been conducted in the public sector, especially in a municipal context.

In the public sector, SCM is concerned with the "coordination of all parties involved in delivering the combination of inputs, outputs or outcomes that will meet a specified public sector requirement". $\mathrm{SCM}$ in the public sector addresses different focus areas. The focus of SCM can differ from government sector-to-sector and SCM can differ from industry sector-to-sector. An example of a government sector-to-sector focus area could be in the health sector, where the focus may be more on logistics and the effective movement of goods and services in and out of hospitals, whereas SCM in the education sector may focus on streamlining the chain through which teaching materials are delivered to students. The shape of the supply chain and the SCM processes employed will vary considerably depending on a range of different considerations (Office of Government of Commerce [OGC], 2005).

Public sector SCM offers a reference framework for the composition of public sector supply chains and multilevel networks (Migiro \& Ambe, 2008). Actors 
in the public sector supply chain comprise (1) private firms which receive orders from public sector agents, (2) accounting officers and (3) policymakers. The SCM in the public sector not only concentrates on the question, which institutions cooperate in goods and services, but also how these enterprises are involved with enterprises operating at other levels. Therefore, analyses of intranet work, as well as of internet work relationships are essentially necessary elements of the concept.

\section{Municipal supply chain management prac- tices in South Africa}

This section of the article provides a background to municipal SCM, understanding municipal SCM processes, as well as the SCM business model.

2.1. Background to municipal SCM practices. SCM, in the South African municipal context, is a financial management tool that seeks to reform and regulate the manner in which public funds are utilized when procuring goods and services while in pursuit of service delivery that is responsive to the needs of society and to curtail any maladministrative and fraudulent practices on the procurement front. It is an integral part of the South African public sector financial management.

According to National Treasury [NT] (2005), SCM can be defined as "an integral part of financial management that seeks to introduce internationally accepted best practice. It bridges the gap between traditional methods of procuring goods and services and the balance of the supply chain whilst addressing procurement related matters that are of strategic importance”.

According to the NT (2005), the concept of SCM was adopted in 2005 due to deficiencies in the public procurement processes (previously known as the tender board system). Procurement reform processes in the South African public sector were initiated and directed at the promotion of principles of good governance, and the introduction of a preference system to address socioeconomic objectives (Ngobeni, 2011, p. 29). However, the system resulted in a lack of accountability, and improper application and implementation of the Preferential Procurement Policy Framework Act 5 of 2000 (PPPFA) (Wall, Watermeyer \& Pirie, 2012, p. 1). The purpose of the adoption of SCM in South African municipalities was to introduce internationally accepted best procurement practice principles, while at the same time addressing the government's preferential procurement policy objectives (Office of Government of Commerce [OGC], 2005). SCM is aimed at adding value at each stage of the procurement process, from the demand of goods or services to their acquisition, managing the logistics process and finally, after use, to their disposal (NT, 2005). In doing so, it needs to address deficiencies in current practices related to procurement, contract management, inventory and asset control and obsolescence planning (NT, 2003; Mkhize, 2004). The SCM process is guided by policies and regulations. The National Treasury developed an SCM policy which was to be adopted by all government entities to suit their needs. Based on the adoption of SCM, the various spheres of government had to adopt the policy to suit their needs, and to give considerations to relevant legislation and regulations guided by the SCM business model. In this article, the focus is on municipalities.

\subsection{Understanding municipal SCM processes. In}

South Africa, municipalities are governed according to the structure of local government, dealt with in terms of the Municipal Structures Act 117 of 1998. This Act sets out the categories and types of municipalities and provides for elections and other matters. The Local Government: Municipal Structures Act 117 of 1998 defines a municipality as "an organ of state within the local sphere of government consisting of political structures, office bearers and administration of the municipality". The Constitution of the Republic of South Africa, 1996 provides for three categories of municipalities. These are Category A (metropolitan), Category B (district) and Category $\mathrm{C}$ (local). There are 278 municipalities in South Africa, comprising eight metropolitan, 44 district and 226 local municipalities (NT, 2013). District municipalities are made up of a number of local municipalities that fall in one district. Typically, there are between four to six local municipalities that fall under one district council (SA Yearbook, 2014, 2015).

Municipal SCM processes are complex and comprehensive and are subject to several pieces of legislation. The key Acts, regulations and guidelines guiding SCM in municipalities are (Smart Grids team, 2014, p. 2):

- Municipal Finance Management Act 56 of 2003 (MFMA).

- Municipal Systems Act 32 of 2000.

- Preferential Procurement Policy Framework Act 5 of 2000.

- Preferential Procurement Regulations 2011.

- Supply Chain Management: A Guide for Accounting Officers of Municipalities and Municipal Entities 2005.

SCM processes have been developed in accordance and in conjunction with other pieces of legislation to develop and shape the SCM within municipalities. These include section 217 of the Constitution, which compels all organs of state to implement a SCM system which is fair, transparent, equitable, 
competitive and cost-effective. Chapter 11 of the MFMA compels municipalities to establish SCM units and implement the SCM policy, which gives effect to all SCM functional areas. The Preferential Procurement Policy Framework Act 5 of 2000 provides for the application of the points system when evaluating and adjudicating bids. Treasury Regulations 868 of 2005 (SCM Regulation) and SCM: A Guide for Accounting Officers of municipalities and municipal entities provides a step by step illustration for the implementation of the SCM policies for the accounting officers. Table 1 summarizes the SCM role players in municipalities.

Table 1. Key role players and functions in municipal SCM

\begin{tabular}{|l|l|}
\hline \multicolumn{1}{|c|}{ Role player } & \multicolumn{1}{c|}{ Function } \\
\hline National Treasury & Develops policy and oversees the implementation of the policy in all municipalities \\
\hline Provincial Treasury & $\begin{array}{l}\text { Supports the municipalities in implementing the SCM policy and further provides assistance to the municipalities in terms of } \\
\text { capacity building }\end{array}$ \\
\hline Municipal council & Approves the SCM structure of the municipality and ensures that the accounting officer executes the council's SCM policy \\
\hline Accounting officer & $\begin{array}{l}\text { Establishes the SCM unit, which will be under the supervision of the CFO. Each municipality in terms of section } 165 \text { of the } \\
\text { MFMA is required to establish an Internal Audit unit that must examine and report on the effectiveness, efficiency and econom- } \\
\text { ic use of SCM to achieve the objectives of the municipality }\end{array}$ \\
\hline External auditors & Examine and report on the compliance of the municipalities with the SCM policy to the Mayor of the municipality \\
\hline SCM officials & $\begin{array}{l}\text { Custodians of the SCM process implement the policy and carry out the SCM operational activities. External role players are the } \\
\text { suppliers and the community within the municipal jurisdiction }\end{array}$ \\
\hline
\end{tabular}

Source: adapted from NT (2005)

Each municipality in terms of section 165 of the MFMA is required to establish an Internal Audit unit that must examine and report on the effectiveness, efficiency and economic use of the SCM to achieve the objectives of the municipality. External auditors examine and report the compliance of the municipalities with the SCM policy to the Mayor of the municipality. The audit committee renders an advisory service to the municipal council, political office-bearers, accounting officers and management of the municipality on matters relating to section
2 (a) I - ix of the MFMA. SCM officials, who are the custodians of the SCM process, implement the policy and carry out the SCM operational activities. External role players are the suppliers and the community within the municipal jurisdiction.

Municipal SCM policy requires the creation of bid committees. The various committees to be created include: the bid specification committee, bid evaluation committee and the bid adjudication committee. Table 2 shows the bid committees, their constituent and roles.

Table 2. Bid committees, constituent and roles

\begin{tabular}{|l|l|}
\hline \multicolumn{1}{|c|}{ Bid committee } & \multicolumn{1}{c|}{ Constituent of the committee and functions } \\
\hline $\begin{array}{l}\text { Bid specification } \\
\text { committee }\end{array}$ & $\begin{array}{l}\text { Comprises of one or more officials, preferably a manager responsible for the function including external specialist advisors (cross-functional } \\
\text { principle); accounting officers or delegated official to appoint as chairperson } \\
\text { ROLES: Compile technical specifications; terms of reference; requirements; conditions of contract; evaluation criteria; determine goals; and } \\
\text { indicate method of procurement }\end{array}$ \\
\hline $\begin{array}{l}\text { Bid evaluation } \\
\text { committee }\end{array}$ & $\begin{array}{l}\text { Comprises of a SCM practitioner; technical expert from the department requiring the good/service. } \\
\text { ROLES: Accounting officer must appoint the chairperson and members; evaluate bids in accordance with the criteria (PPPFA); evaluate } \\
\text { bidders' tax matters; submit a report for recommendation regarding the award; check list for restricted bidders; consult the register for tender } \\
\text { defaulters }\end{array}$ \\
\hline $\begin{array}{l}\text { Bid adjudication } \\
\text { committee }\end{array}$ & $\begin{array}{l}\text { Comprises of at least four senior managers which include: the CFO; at least one senior SCM practitioner to ensure compliance and a } \\
\text { technical expert who is an official to ensure compliance with the specification. } \\
\text { ROLES: Accounting officer must appoint the chairperson and members; a member of the bid evaluation committee may present its case to } \\
\text { the bid adjudication committee; neither a member of the bid evaluation committee nor a person assisting it, or any advisor,may be a mem- } \\
\text { ber of this committee. }\end{array}$ \\
\hline
\end{tabular}

Source: adapted from NT (2005).

SCM in municipalities is considered an under-girdle for spending on capital projects and operational expenditure (day-to-day expenses), monitoring the manner in which the spending is undertaken, fostering spending that advances the RDP goals, LED initiatives, BBBEEA principles and ensuring value for money on each spending.
2.3. Municipal SCM business model. According to the SCM guide for accounting officers, SCM in the South African public sector is guided by the SCM model. The model consists of six elements of SCM, namely demand, acquisition, logistics, disposal, risk management and performance evaluation (Mnguni, 2012). Figure 1 presents the municipal SCM business model. 


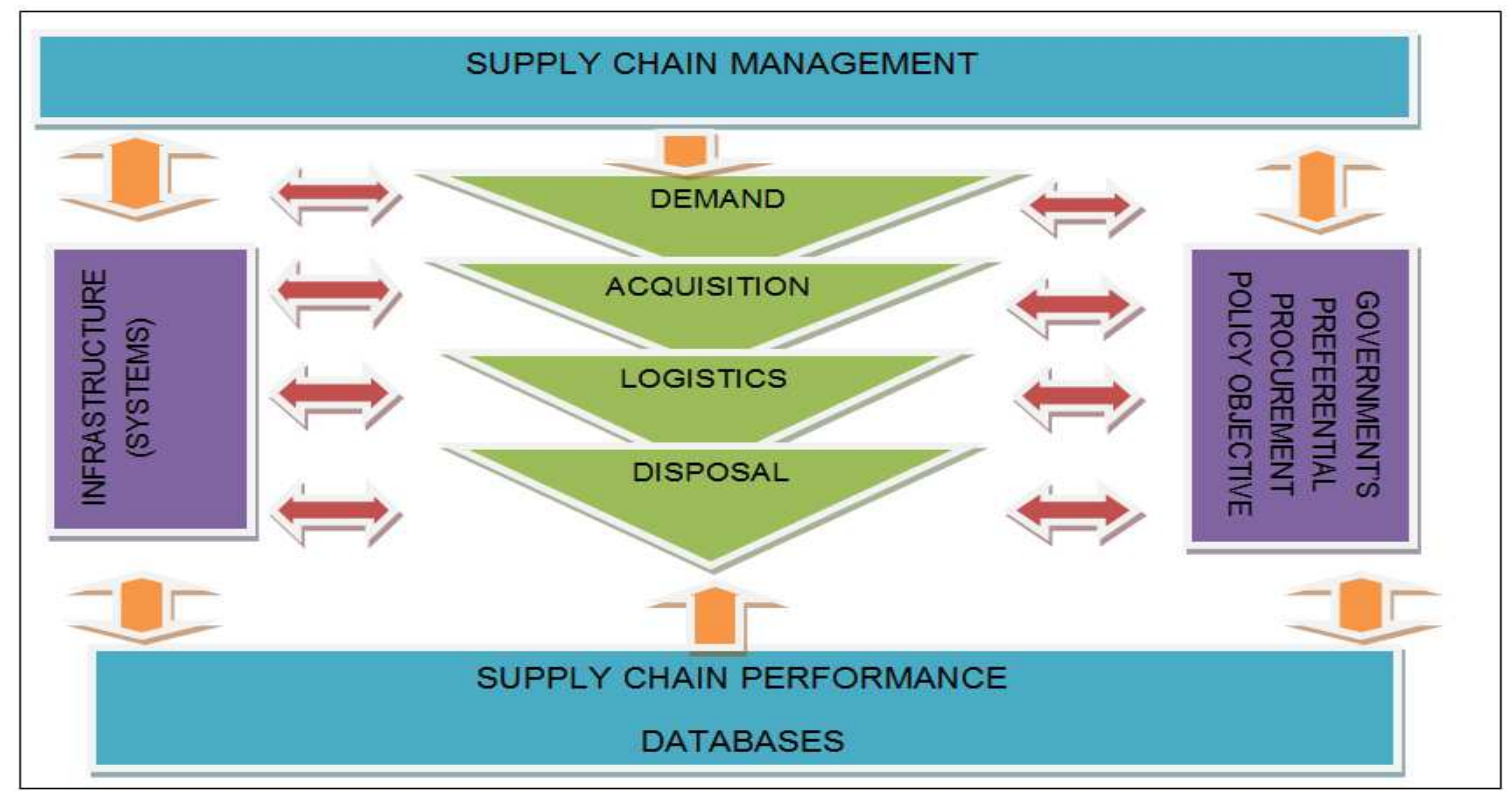

Fig. 1. Municipal SCM business model

Source: National Treasury (2005, p. 10).

The six elements of SCM are briefly discussed:

- Demand management: this is the first element of SCM. It is aimed at fulfilling the needs identified during the strategic planning process. The total needs assessment should have been undertaken before the process can start. Resources required must be analyzed and assessed, and key elements in the demand management process should be considered and bring the SCM practitioner closer to the end users.

- Acquisition management: the management of procurement includes the evaluation of bids, the composition of bid committees, and the compilation of a register for defaulters, the range of procurement systems, and the establishment of total cost of ownership of assets, bid adjudication and the appointment of consultants.

- Logistics management: this implies to strategically manage acquisition, the movement and storage of materials, the cost fulfilment of orders, to ensure the effective flow of goods, services and related information from the point of origin to the point of consumption.

- Disposal management: the management of assets that are no longer needed gave rise to the need for obsolescence planning, which implies the creation of a database of redundant materials, the inspection of materials for re-use, and to determine the disposal strategy and methods of execution.

- Risk management: this refers to the management of unintended or unexpected outcomes of a decision and makes provision for identifying, considering and avoiding risk as well as the provision for adequate cover for residual risks.
- Supply chain performance: this monitors the progress undertaken in a retrospective analysis to determine whether the processes have been followed and if the desired objectives were achieved. The National Treasury template for measuring performance is used.

These elements are the basis on which an efficient SCM system is implemented across all spheres of government, including municipalities. SCM is an integral part of financial management in municipalities. To be able to provide a perspective of SCM, it is important to review the transformation processes leading up to the adoption of SCM.

\section{Current status of supply chain management practices in municipalities}

In order to understand the current status of SCM in a municipal context, a case analysis of SCM practices based on the Auditor General reports (2010 to 2014) are discussed, as well as the challenges of implementing municipal SCM practices for a national perspective.

\subsection{Case analysis of SCM practices of municipal-} ities in a province in South Africa. The province under analysis consists of 23 municipalities and three municipal entities. As indicated in section 2.2, municipalities in South Africa are categorized into metropolitan, district and local municipalities. The municipalities are made up of four district municipalities and 19 local municipalities. The municipalities operate on a budget of R15.9 billion (operating expenditure: R12.2 billion and capital expenditure: R3.7 billion) in the financial year 2013/2014 (AG, 2014). The four largest service delivery departments in the province, namely Education and Sports De- 
velopment, Health, Public Works and Roads, and Local Government and Human Settlements, manage $76 \%$ of the provincial budget (AG, 2015). The province was selected for analysis for the sake of convenience and because it is one of the worst performing provinces on SCM, as well as service delivery.

The Auditor General (Chapter 9 institution) provides an audit report on the state of financial management in the country on an annual basis. SCM is a key component of the report, as it is an integral part of financial management in the public sector. A high prevalence of non-compliance with SCM legislation led to irregular expenditure. Irregular expenditure is "expenditure that was not incurred in the manner prescribed by legislation". Table 3 presents SCM practices in the municipalities, according to the Auditor General's reports 2010-2014. Five major constructs as used by the Auditor General to determine compliance were used. The constructs are important variables used in the reports and do not sum up to $100 \%$ in this article, as they reflect supply chain activities of different years. Table 3, therefore, portaries a reflection of SCM practices in the years and was compiled to substantiate the argument of this article.

Table 3. State of SCM practices in municipalities of the case province

\begin{tabular}{|c|c|c|c|c|}
\hline SCM practice & 2010-2011 & 2011-2012 & $2012-2013$ & 2013-2014 \\
\hline Awards to employees and councillors or other state officials & $39 \%$ & $59 \%$ & $37 \%$ & $24 \%$ \\
\hline Awards to close family members of employees and councillors & $11 \%$ & $33 \%$ & $19 \%$ & $16 \%$ \\
\hline Uncompetitive or unfair procurement processes & $79 \%$ & $93 \%$ & $81 \%$ & $76 \%$ \\
\hline Inadequate contract management & $32 \%$ & $37 \%$ & $41 \%$ & $52 \%$ \\
\hline Inadequate controls & $86 \%$ & $96 \%$ & $81 \%$ & - \\
\hline
\end{tabular}

The state of SCM practices in the municipalities is discussed according to the SCM practices:

- Awards to employees and councillors or other state officials. SCM regulation 44 prohibits awards to persons or entities owned/managed by them if they are in service of the auditee (i.e., employees and councillors) or if they are in service of any other state institution. Such expenditure is also considered irregular. The audit included the identification of such prohibited awards. Table 3 reveals that tenders are still being awarded to state officials with the year 20112012 being the highest percentage (59\%), while $39 \%$ was recorded in 2010-2011. This situation slightly improved in 2012-2013 (37\%). In the financial year 2013-2014, 24\% of the contracts were awarded to employees and councillors.

- Awards to close family members of employees and councilors. The SCM policy also prohibits tenders to be awarded to persons or entities owned/managed by persons who are close family members of persons in the service of the state, whether at the auditee or at any other state institution. Table 3 reveals that in the year 2010$2011,11 \%$ of tenders were awarded to close family members, with an increase to $33 \%$ in 2011, a decline to $19 \%$ in $2012-2013$ and in 2013-2014.

- Uncompetitive or unfair procurement processes. Uncompetitive or unfair procurement processes in the findings relate to three written quotations not invited without a deviation approved or with an approved deviation that was not reasonable or justified; competitive bids that were not invited when it was required to do so and the deviation was not approved or an approved deviation was not reasonable or justified and procur- ing goods/services from suppliers without making sure that the supplier obtained a tax clearance certificate. Table 3 reveals that noncompliance with procurement processes were relatively high for the municipalities in 20112012 (93\%), while in 2010-2011, it was 79\% and a decline compared to the other years in $2012-2013$ with a percentage of $81 \%$. In 2013 2014 , it was $76 \%$.

- Inadequate contract management. It was of great concern that the performance of contractors at municipalities was not monitored on a monthly basis and inadequate contract management and monitoring was found. Compared to the previous findings, Table 3 reveals a gradual increase in inadequate contract management procedures ranging from $32 \%$ in $2010-2011 ; 37 \%$ in $2011-2012$ and $41 \%$ in the financial year 2012-2013. Furthermore, in the year 2013-2014, inadequate contract management amounted to $52 \%$.

- Inadequate controls. SCM internal control measures noteworthy in the findings are inadequate controls to ensure employees and councillors declare their own interest and those of their close family; no plans are in place for addressing past audit findings on SCM or adherence to the plan was not monitored regularly; no/inadequate record-keeping; SCM officials were not adequately trained and no inadequate actions were taken to address the SCM risks. Table 3 reveals that the municipalities are highly not complying with SCM internal control measures. 2012-2013 recorded very high inadequate measures of $96 \%$, while 2010-2011 recorded $86 \%$. This situation was slightly improved in 2012-2013 compared to the previous financial year with a percentage of $81 \%$. 
From the discussions above, it is evident that the municipalities in the province do not comply with supply chain policies and practices. SCM remains a challenge in the province, with irregular expenditure incurred amounting to R1, 899 million (AG, 2014). The municipalities did not comply with SCM policies and regulation by issuing contracts to employees and councillors or other state officials, awards to close family members of employees and councillors, uncompetitive or unfair procurement processes and inadequate contract management and controls. Therefore, SCM is not adequately implemented in the municipalities. These findings support claims by Nomvette (2011), who expressed concern that SCM processes at municipalities were being handled in a way that financially benefits a few individuals and that laws and regulations governing SCM are intentionally ignored or flouted by government officials in order to give state officials and their families and associates unfair advantage over other competitors or would-be service providers to government.

3.2. Municipal SCM challenges. Following the case analysis, it is imperative that municipalities in the province face enormous SCM challenges. This situation is not unique to only this province, but is a challenge to municipalities in general. The challenge may be as a result of a need for appropriate understanding regarding the concept of SCM and its inextricable link to long-term quality service delivery, human capital development and associated socioeconomic growth (Boateng, 2008). NT (2015) revealed that municipalities are challenged by constant allegations of corruption and inefficiency. In daily reports in newspapers, on television, radio and social media, there is evidence of irregularities in SCM. Few municipalities are starting to value the strategic importance of SCM to service delivery, value creation, socioeconomic transformation and fiscal prudence. The establishment of the office of the Chief Procurement Officer within the National Treasury reflects government's commitment to quality service delivery at the right place and time (NT, 2015, p. 1).

Some of the key challenges for inappropriate SCM in municipalities are due to:

- Strategic importance of SCM. Currently, SCM falls under the finance department in government. It has not been seen as a core and strategic discipline and, therefore, the strategic importance of SCM is not valued. Ellram and Cooper (2014) indicated certain guidelines and principles for a concept to be a discipline. Based on those guidelines, SCM should be given a strategic status as a discipline and should not fall under the finance division within government spheres.
- Lack of organizational structures and systems in place. Since the implementation of SCM, many municipalities do not have appropriate organizational structures and systems in place partly owing to a lack of skills, knowledge and capacity. Also, there has been a lack of strategic leadership and shared vision (SCM Review, 2015).

- Lack of compliance and accountability. Many SCM defaulters have not been held accountable. Municipal SCM practitioners who have defaulted in processes have been able to move jobs within government without any action being taken against them. There is, therefore, an urgent need to rethink innovative ways of curbing corruption and some other administrative malpractices within municipalities. There must be consequences for those who are not willing to play their part for the public good (NT, 2015).

- Lack of clarity of roles and responsibility. The lack of clarity about the roles and responsibilities of technical staff and of political office-bearers creates scope for interference, and this gives rise to allegations or instances of corruption.

- Lack of skills, knowledge and capacity. While the system contains many excellent people, competency assessments show significant gaps in SCM skills and knowledge (NT, 2015). Many municipal SCM actors have attended a number of training workshops on SCM, but they still lack the appropriate knowledge for proper implementation (NT, 2015). The national and provincial treasuries embark on programes that educate practitioners, but implementation of its programmes always falls short.

- Policies and regulations overlap, are confusing and cumbersome. SCM-related policies and regulations are numerous, often confusing and cumbersome. This creates confusion not only to SCM practitioners as custodians, but also to suppliers. This inhibits proper implementation thereby leading to poor service delivery. Ambe and Badenhorst-Weiss (2012) noted that there are inadequate controls and procedures for the handling of bids, appointment of bid committee members not aligned to policy requirements and insufficient motivation for deviations from SCM procedures.

- Lack of supplier management relationships. Supplier relationship management is an important part of SCM. However, municipalities underestimate how important supplier management is. This is sometimes misunderstood to be linked to corruption. Municipalities in the country need to foster long-term strategic supplier relationships with their suppliers.

- Ethical and professionalism. There has been lack of ethics and professionalism among mu- 
nicipal SCM practices. This is evident in the daily newspapers and on social media and has resulted in different approaches and a lack of standardization. According to McCarthy (2006), the completeness of tender documents in many municipalities is difficult to verify. De Lange (2011) notes that taxpayers were fleeced of R30 billion [3.675 billion USD]. Among government entities probed for procurement irregularities was the Tshwane metro where about 65 municipal officials were investigated for striking business deals worth about R185 million with their own Council (Pauw, 2011).

\section{The way forward for municipal supply man- agement}

It is important that these challenges are addressed to give effect to the SCM process. The SCM policy was meant to ensure that procurement is always carried out strictly according to the legislation in place, so as to avoid wasteful expenditure, conflicts of interest and unfair treatment of service providers. In practice, it has proved to be extremely onerous and time-consuming, with government audits identifying numerous cases where the SCM has gone wrong in various ways. SCM, therefore, does not appear to be working as envisaged. Currently, there is a move towards a more centralized procurement system. Whether or not this will help, or if it will just slow things down even further, remains to be seen. Meanwhile, the best approach for municipalities, project developers and vendors is to get to know the SCM processes in detail and to remember that each municipality generally has slightly different implementations of SCM. It is suggested that the following should be considered for proper implementation of SCM in South African municipalities:

- Involvement of the community. All citizens across communities should be part of the SCM process. This could be by way of community engagements. The communities should be aware of tenders in their municipalities and their engagement through community workshops and open briefing sessions. In this light, the community will be aware of projects to be launched for bids and will, in turn, monitor the SCM process.

- Understanding the SCM policy and its processes. Municipal officials should understand the prescribed SCM policy and processes to accelerate the elimination of SCM process irregularities. It is imperative that every accounting officer/authority, chief financial officer and senior official needs to discharge their MFMAprescribed obligations diligently. It is important that reasonable steps be taken to prevent irregular expenditure by developing and implementing internal control systems that ensure fair, equitable, transparent, competitive and cost-effective SCM processes that could prevent and detect fraud, non-performance by suppliers, and noncompliance with SCM legislation.

- Strong ethical leadership. In the current climate of SCM practices in municipalities, ensuring a strong ethical culture is critical. Noncompliance with SCM across the management of municipalities should have consequences and accountability should be enforced. Political and municipal leadership need to take action against transgressors. Only when the leadership has set that tone of decisively dealing with such malpractices would the citizenry have confidence in the SCM systems.

To conclude, SCM is the area where the bulk of the activities are concentrated in municipalities. Continued non-adherence to SCM regulations, therefore, defers restoration of the publics' confidence in the ability of municipalities to systematically take care of their interests - and deprives citizens of much needed services in all areas of service delivery. The level of service delivery to citizens and the degree to which socioeconomic objectives are promoted are directly and significantly helped or frustrated by the degree to which the SCM systems of municipalities comply with legislation and prescripts.

\section{Conclusion}

SCM is an important concept in today's business environment, as it contributes significantly to the bottom line (Agus, 2011, p. 269). Many professional government organizations have indicated that SCM could hold great promise in enhancing public procurement systems. In South African municipalities, it is a key tool and mechanism enabling government to implement policy for socioeconomic development and transformation. Traditionally, SCM has been misunderstood and undervalued. However, to date (2005-2016), SCM in municipalities over the years has been characterized by fraud and corruption despite the effort of the National Treasury. This article presents an insight into SCM practices in a municipal context in South Africa. This article based on a theoretical review reveals that the focus of SCM differs from government sector-to-sector and from industry sector-to-sector. The context of SCM in South African municipalities is based mainly on compliance with legislation. The municipal SCM processes have been developed in accordance and in conjunction with other pieces of legislation to develop and shape the SCM within municipalities.

Municipalities in the case study province did not comply with supply chain policies and practices. The municipalities face challenges of non- 
compliance and irregular expenditure. SCM processes at municipalities were being handled in a way that financially benefits a few individuals and that laws and regulations governing SCM are intentionally ignored or flouted by government officials in order to give state officials and their families and associates unfair advantage over other competitors or would-be service providers to government. To a great extent the intended outcomes for the adoption of SCM have not fully been achieved. While some municipalities are improving, the majority of municipalities still derail due to supply chain failures. Therefore, SCM have been offered a strategic posi- tion and the office of the Chief Procurement Officer was established to oversee and reinforce the implementation of SCM. It is suggested that the communities within municipalities should play an active role through community engagements. SCM is paramount to the success of the country in terms of meeting its socio-economic objectives, service delivery and good governance to the municipal environement. It is very important for municipal SCM officials to understand the governing policies and regulations provided by the National Treasury on SCM. Strong ethical leadership is required to move SCM to a strategic level.

\section{References}

1. Agus, A. (2011). The structural influence of supply chain management on product quality and business performance, International Journal of Trade, Economics and Finance, 2 (4), pp. 269-275.

2. Arlbjørn, J.S., Freytag, P.V. \& de Haas, H. (2011). Service supply chain management: a survey of lean application in the municipal sector, International Journal of Physical Distribution \& Logistics Management, 41 (3), pp. $277-295$.

3. Ambe, I.M. \& Badenhorst-Weiss, J.A. (2012). Procurement Challenges in the South African Public Sector, Journal of Transport and Supply Chain Management, 6 (1), pp. 242-261. Doi: 10.4102/jtscm.v6i1.63.

4. Bent, R.A. (2014). The significance of supply chain management with regard to the attainment of value and strategic objectives for municipalities within South Africa: a case study (Master's Thesis), Science at Stellenbosch University, South Africa.

5. Boateng, D. (2008). Government service delivery lies in supply chain management, not centralised procurement, smart procurement [online]. Available at: http://www.smartprocurement.co.za [accessed 10 February 2012].

6. Business Day. (2011). Irregular state expenditure jumps 62\%. Smart procurement [online]. Available at: http://www.smartprocurement.co.za/archives/irregular_state_expenditure_jumps_62.php [accessed 10 February 2012].

7. Council of Supply Chain Management Professionals (CSCMP). (2007). [Online]. Available at: http://www.cscmp.org [accessed 21 January 2016].

8. De Haas, R. (2011). Microfinance at the margin: Experimental evidence from Bosnia and Herxegovina. Mimeo.

9. Ellram, L.M. \& Cooper, M.C. (2014). Supply chain management: it's all about the journey, not the destination, Journal of supply chain management, 50 (1), pp. 8-20.

10. Institution for supply chain management (2014). [Online]. Available at: http://www.ioscm.com/ [accessed 17 August 2015].

11. Korosec, R.L. (2003). Assessing the feasibility of supply chain management within purchasing and procurement, Public Performance and Management Review, 27 (2), pp. 92-109.

12. Mkhize, Z.L. (2004).Transforming government procurement system, Supply Chain Management Conference, November, Durban, Republic of South Africa, pp. 22-23.

13. Migiro, S.O. \& Ambe, I.M. (2008). Evaluation of the implementation of public sector supply chain management and challenges: a case study of the central district municipality, North-West Province, South Africa, African Journal of Business Management, 2 (12), pp. 230-242.

14. Mnguni, N. (2012). To investigate and evaluate the implementation of the supply chain management in service delivery with specific focus on procurement processes of goods and service in the head office of the Eastern Cape Department of Health. Nelson Mandela Metropolitan University: Faculty of Business and Economic Sciences.

15. McCarthy, N.G. (2006). Report of the Auditor-General, Free State, Bloemfontein, 30 June, pp. 1-7.

16. National Treasury. (2003). Policy strategy to guide uniformity in procurement reforms processes in government. Republic of South Africa.

17. NT, vide National Treasury.

18. National Treasury. (2005). Supply chain management: a guide for accounting officers and municipal entities. Republic of South Africa.

19. National Treasury. (2013). Delivering municipal services in rural areas (PDF), National Treasury of South Africa, p. 3. [accessed 30 April 2013].

20. National Treasury. (2015). 2015 Public sector supply chain management review. Pretoria.

21. Nomvette, T. (2011). A keen focus on supply chain management by government will help to build confidence in our democracy [online]. Available at: http://www.agsa.co.za/Media/Previouscolumns/tabid/237/ArticleID/125/Akeen-focus-on-supply-chain-management-by-government-will-help-to-build-confidence-in-our-democracy.aspx [accessed 20 April 2016].

22. Ngobeni, S. (2011). An analysis of the tender process in national government in South Africa. MBA Thesis, NorthWest University, Potchefstroom Campus [online]. Available at http://dspace.nwu.ac.za [accessed 3 December 2015]. 
23. Office of Government of Commerce. (2005). Supply chain management in public sector procurement: a guide version, 6 June.

24. OGC, vide Office of Government of Commerce.

25. Pauw, J.C. (2011). Public procurement and supply chain management. Study guide: programme in Public Procurement and Supply Management. Pretoria: Centre for Business Management, University of South Africa.

26. Smart Grid project team. (2014). Understanding Municipal Procurement Processes [online]. Available at: http://greencape.co.za/smartgrids/docs/D6.pdf [accessed 20 April 2016].

27. South Africa Yearbook 2014/15 [online]. Available at: http://www.gcis.gov.za [accessed 14 January 2016].

28. Turley, L. and Perera, O. (2014). Implementing Sustainable Public Procurement in South Africa: Where to start? Manitoba: International Institute for Sustainable Development. 